\title{
Peluang Kematian Penderita Human Immunodeficiency Virus-Acquired Immune Deficiency Syndrome berdasarkan Gabungan Derajat Anemia, Indeks Massa Tubuh, dan Jumlah Cluster Differentiation 4
}

\author{
Rachmat Sumantri, ${ }^{1}$ Iman Supandiman, ${ }^{1}$ Ponpon Indjradinata, ${ }^{2}$ Andre van der Ven, ${ }^{3}$ \\ Reinout van Crevel ${ }^{3}$
}

${ }^{1}$ Departemen Ilmu Penyakit Dalam, ${ }^{2}$ Departemen Ilmu Kesehatan Anak Fakultas Kedokteran

Universitas Padjadjaran-Rumah Sakit Dr. Hasan Sadikin Bandung, ${ }^{3}$ Radboud University Netherlands

\begin{abstract}
Abstrak
Prevalensi anemia pada infeksi human immunodeficiency virus (HIV) cukup tinggi, berkisar antara 1,3\% sampai $95 \%$ bergantung pada stadium penyakitnya. Anemia, cluster differentiation 4 (CD4), dan viral load (VL) merupakan faktor risiko independen untuk kematian. Indeks massa tubuh (IMT) merupakan faktor risiko yang penting untuk anemia dan progresivitas penyakit. Dilakukan penelitian kohor untuk mengevaluasi respons pengobatan selama follow-up 6 bulan dengan endpoint kematian, serta menghitung peluang kematian penderita acquired immunodeficiency syndrome (HIV-AIDS) berdasarkan gabungan derajat anemia, IMT, dan jumlah CD4. Subjek penelitian adalah penderita HIV-AIDS di klinik Teratai Rumah Sakit Dr. Hasan Sadikin (RSHS) Bandung, periode Januari-Juni 2008, studi kohor dilakukan pada periode Juli-Desember 2008. Tercatat 534 penderita HIVAIDS yang masuk dalam data di klinik Teratai RSHS, sampai akhir penelitian terdapat 458 penderita yang masih aktif berobat, 38 penderita drop-out, 8 penderita pindah ke tempat lain, dan 28 penderita meninggal. Prevalensi anemia kelompok yang sama pada penelitian sebelumnya yaitu 41,6\%. Dalam follow-up selama 6 bulan terdapat 26 kematian pada kelompok anemia dan hanya 2 kematian pada kelompok nonanemia. Gabungan antara derajat anemia sedang-berat, dengan CD4 $\leq 50 / \mathrm{mm}^{3}$, dan IMT $<18,5$ menunjukkan peluang kematian terbesar, dalam penelitian ini sebesar $80 \%$. Simpulan, faktor risiko yang penting untuk kematian pada penderita HIV-AIDS yaitu jumlah CD4, derajat anemia, dan IMT. [MKB. 2012;44(1):50-6].
\end{abstract}

Kata kunci: Anemia, CD4, indeks massa tubuh

\section{Opportunity of Death in Human Immunodeficiency Virus-Acquired Immunodeficiency Syndrome Patients by Combining Degree of Anemia, Body Mass Index, and Cluster Differentiation 4 Count}

\begin{abstract}
The prevalence of anemia in human immunodeficiency syndrome (HIV) infection was quite high, ranging from 1.3 to $95 \%$ depending on the stadium of HIV infection. Anemia, cluster differentiation 4 (CD4), and viral load were known as the independent risk factors for death. Body mass index (BMI) is an important risk factor for anemia and progression of the HIV infection. A cohort study had been conducted to evaluate the response of therapy, and deaths as the end point, and to calculate the opportunity of death by combining the degree of anemia, BMI, and CD4 in HIV-AIDS patients. The subjects were patients in Teratai Clinic Dr. Hasan Sadikin General HospitalBandung from January to June 2008. During 6 months of follow-up from July-December 2008, there were 534 patients in the database of Teratai Clinic, with only 458 continuing the therapy, thirty eight patients were dropped-out, eight patients moved to other hospital and 28 patients died. The prevalence of anemia from previous study of those 534 patients was $41.6 \%$. After 6 months of follow-up, there were 26 deaths among anemic patients and 2 deaths in non-anemic patients. The combination of moderate-severe anemia, CD $4 \leq 50 / \mathrm{mm}^{3}$ and BMI $<18.5$ showing the highest opportunity of death in this study was $80 \%$. In conclusion, the important risk factors of deaths in HIV-AIDS patients were CD4, grade of anemia, and BMI. [MKB. 2012;44(1):50-6].
\end{abstract}

Key words: Anemia, body mass index, CD4 Korespondensi: Dr. Rachmat Soemantri, dr., Sp.PD-KHOM, Departemen Ilmu Penyakit Dalam Fakultas Kedokteran
Universitas Padjadjaran-Rumah Sakit Dr. Hasan Sadikin Bandung, jalan Pasteur 38 Bandung, telepon (022) 2044234, mobile0811218393, e-mail rsumantri@yahoo.com 


\section{Pendahuluan}

Infeksi human immunodeficiency virus (HIV) yang menyebabkan acquired immune deficiency syndrome (AIDS) mulai dikenal sejak tahun 1983. Sampai akhir tahun 2007 sudah menyebabkan infeksi pada 33,2 juta penduduk dunia dan menyebabkan kematian 2,1 juta penduduk. Setiap hari lebih dari 6.800 penderita terinfeksi HIV dan 5.700 meninggal karena AIDS, yang berarti satu orang meninggal setiap 15 detik. Pada tahun 2007 terdapat 2,5 juta kasus infeksi HIV baru, angka ini naik $15 \%$ dari tahun 2001, saat itu United Nations Programme on Aqcuired Immune Deficiency Syndrome (UNAIDS) melaporkan 29 juta penduduk dunia terinfeksi HIV, dengan 1,7 juta kematian.,

Penyakit ini mulai dikenal di Indonesia pada tahun 1987 pada seorang wisman di Bali dan sejak itu jumlah penderita HIV-AIDS di Indonesia terus meningkat. Di klinik Teratai Rumah Sakit Dr. Hasan Sadikin (RSHS) Bandung sejak Desember 1996 sampai akhir 2007 tercatat 1.091 kasus infeksi HIV, sebanyak 660 kasus di antaranya sudah dalam stadium AIDS dan 331 penderita tersebut masih aktif menggunakan obat antiretroviral (ARV) sesuai dengan program pemerintah yang dimulai sejak September 2004. Data di klinik Teratai RSHS sampai dengan akhir Desember 2008 tercatat 1.593 kasus infeksi HIV, sebanyak 1.009 kasus di antaranya adalah AIDS, 496 penderita aktif menggunakan ARV. Tercatat pula bahwa $68,9 \%$ penderita merupakan pengguna narkoba suntik (intravenous drug user/IDU). Menurut World Health Organization (WHO), Indonesia merupakan salah satu negara dengan pertumbuhan kasus infeksi HIV yang sangat cepat, dengan perkiraan lebih dari 200.000 penderita. ${ }^{3}$

Prevalensi anemia pada infeksi HIV cukup tinggi, berkisar antara 1,3\% dan 95\% bergantung pada stadium penyakitnya. Semakin lanjut penyakit, maka kejadian anemia juga makin tinggi dan anemia meningkatkan morbiditas serta mortalitas. Anemia tidak langsung menyebabkan kematian akan tetapi jelas mempengaruhi kualitas hidup penderita dan telah terbukti sebagai faktor risiko independen terhadap kematian karena HIV., ${ }^{4,5}$ Prevalensi anemia pada penderita HIV-AIDS di klinik Teratai RSHS sebesar $41,6 \%$ dan faktor risiko yang berperan dalam kejadian anemia yaitu indeks massa tubuh (IMT) yang rendah, cluster differentiation 4 (CD4) 1-50/ $\mathrm{mm}^{3}$, kandidiasis oral, dan obat ARV sebagai faktor protektif. ${ }^{6}$ Volberding dkk. ${ }^{5}$ menyatakan bahwa faktor risiko yang berpengaruh pada perjalanan HIV-AIDS yaitu usia, jenis kelamin, IMT, jumlah CD4 pada awal diagnosis, pemakaian ARV serta ada tidaknya anemia. Menurut Belperio dan Rhew ${ }^{4}$ anemia merupakan faktor risiko independen untuk kematian pada HIV-AIDS, di samping jumlah CD4 dan viral load (VL). Penelitian terdahulu menunjukkan bahwa hal yang berhubungan dengan kematian pada penderita HIV-AIDS yaitu usia, jenis kelamin, IMT, anemia, jumlah CD4, VL, infeksi oportunistik, dan keganasan. Anemia, jumlah CD4, dan VL sudah diketahui merupakan faktor risiko penting untuk kematian. Indeks massa tubuh diketahui juga merupakan faktor risiko penting untuk terjadinya anemia dan progresivitas penyakit. $4,5,7-9$

Di negara berkembang belum semua tempat fasilitas kesehatan dapat memeriksa VL karena keterbatasan biaya. Di Indonesia termasuk di tempat penulis saat melakukan penelitian, pemeriksaan VL belum dikerjakan secara rutin, hanya pada sebagian penderita dapat dilakukan pemeriksaan. Oleh sebab itu, VL sebagai salah satu faktor risiko independen kematian tidak dimasukkan dalam konsep penelitian ini.

Penelitian ini bermaksud untuk menganalisis faktor-faktor risiko yang penting untuk kematian pada penderita HIV-AIDS di Rumah Sakit Dr. Hasan Sadikin, serta apakah gabungan derajat anemia dan faktor risiko kematian lain yaitu IMT dan jumlah CD4, merupakan petunjuk terhadap peluang kematian pada penderita HIV-AIDS.

\section{Metode}

Subjek penelitian yaitu penderita HIV-AIDS yang berobat di klinik Teratai RSHS-Bandung periode Januari-Juni 2008. Pada setiap penderita dilakukan wawancara, pemeriksaan fisis dan laboratorium, serta menandatangani formulir kesediaan ikut dalam penelitian. Data yang diambil merupakan data dari penelitian profil dasar dan respons pengobatan pada penderita HIV-AIDS di RSHS-Integrated Management for Prevention and Control Treatment of HIV-AIDS (IMPACT). Disain penelitian studi kohor untuk menilai respons pengobatan dengan end point kematian. Untuk studi ini variabel bebas yaitu usia, jenis kelamin, IMT, IDU, stadium klinis WHO, tuberkulosis (TB), kandidiasis oral, anemia, adherence (kepatuhan minum ARV), CD4, dan VL. Variabel terikat yaitu kematian.

Jumlah sampel yang diperlukan untuk studi kohor ini dipergunakan Rule of Thumb.

$\mathrm{N}=10 \times 11 / 0,50=220$, jumlah sampel 220 penderita.

Kriteria inklusi yaitu semua penderita infeksi HIV-AIDS yang berobat di klinik Teratai RSHS yang masuk dalam data basis dan menandatangani surat persetujuan kesediaan mengikuti penelitian. Semua subjek yang memenuhi kriteria inklusi dilakukan penghitungan penelitian (intention to treat analysis).

Batasan usia penelitian yaitu 14 tahun ke 
atas. Indeks massa tubuh ditentukan berdasarkan konsensus Perhimpunan Endokrinologi Indonesia (Perkeni) ${ }^{10}$ yaitu berat badan kurang (IMT $\left.<18,5\right)$, berat badan normal (IMT 18,5-22,9), berat badan lebih dengan risiko (IMT 23,0-24,9), obes I (IMT 25,0-29,9), dan obes II (IMT $\geq 30$ ). Stadium klinis WHO terbagi atas 4 stadium, yaitu I sampai IV. ${ }^{11}$ Diagnosis tuberkulosis paru dibuat berdasarkan gejala klinis batuk-batuk, demam, keringat malam, disertai gambaran radiologis terdapatnya infiltrat dengan batang tahan asam (BTA) positif atau negatif, atau riwayat pengobatan tuberkulosis. ${ }^{12}$ Diagnosis kandidiasis oral dibuat secara klinis dengan melihat bercak selaput putih sekitar rongga mulut, lidah, dan bila selaput tersebut diangkat dengan memakai penjepit akan terjadi perdarahan. Antiretroviral yang termasuk dalam program pemerintah dan tersedia saat ini, yaitu golongan nucleoside reverse transcriptase inhibitor, yaitu stavudin (d4T) $30 \mathrm{mg}$, lamivudin (3TC) $150 \mathrm{mg}$, zidovudin (AZT) $300 \mathrm{mg}$ yang digabungkan dengan lamivudin dalam satu kemasan, tenofovir (TDF) 300 mg, kemudian golongan non nucleoside reverse transcriptase inhibitor yaitu nevirapin $200 \mathrm{mg}$ dan efavirenz $600 \mathrm{mg}$, serta golongan protease inhibitor yaitu lopinavir $200 \mathrm{mg} /$ ritonavir $50 \mathrm{mg} .{ }^{13}$ Flowcytometry dengan alat fluorescence activated cell sorting (FACS) dipergunakan untuk memeriksa CD4, satuannya sel/ $\mu \mathrm{L}$, jumlah normal 355-1.213 sel/uL. Viral load (VL) diperiksa di Laboratorium Kesehatan Daerah Provinsi Jawa Barat, pemeriksaan dilakukan dengan metode reverse transcryptase-polymerase chain reaction (RT-PCR) menggunakan Abbot real time HIV-1 (Abbot). Rentang pemeriksaan 150-10.000.000 $\mathrm{kopi} / \mathrm{mm}^{3}$. Nilai normal virus tidak terdeteksi atau kurang dari $150 \mathrm{kopi} / \mathrm{mL}$. Intravenous drug user yaitu penderita infeksi HIV dengan riwayat pemakaian narkoba suntik.

Adherence atau kepatuhan minum obat ARV dinilai dengan jumlah dosis obat yang diminum penderita dalam satu bulan. Adherence baik bila hanya lupa $<3$ dosis obat dalam 30 hari, adherence buruk bila lupa minum obat $>12$ dosis dalam 30 hari, dan adherence sedang bila lupa minum obat 3-12 dosis dalam 30 hari. ${ }^{14}$

Kadar normal hemoglobin ( $\mathrm{Hb})$ untuk lakilaki $14 \mathrm{~g} / \mathrm{dL}$ dan $12 \mathrm{~g} / \mathrm{dL}$ untuk wanita. ${ }^{15}$ Anemia dibagi menjadi anemia ringan ( $\mathrm{Hb} 10-12 / 14 \mathrm{~g} /$ $\mathrm{dL})$, anemia sedang ( $\mathrm{Hb} 7-10 \mathrm{~g} / \mathrm{dL})$, dan anemia berat $(\mathrm{Hb}<7 \mathrm{~g} / \mathrm{dL})$.

Pengumpulan data dilakukan selama periode Januari-Juni 2008, studi kohor dilakukan periode Juli-Desember 2008.

Uji statistik dilakukan dengan regresi logistik multipel. Semua analisis data mempergunakan program komputer statistical product and service solution (SPSS) for Windows versi 15.0

\section{Hasil}

Penelitian pada HIV-AIDS dan pengamatannya sampai enam bulan telah dilakukan terhadap 534 penderita yang masuk dalam data basis di klinik Teratai Rumah Sakit Dr. Hasan Sadikin Bandung periode Januari-Juni 2008. Sampai akhir periode pengamatan yaitu pada tanggal 31 Desember 2008 terdapat 458 penderita yang masih aktif berobat, 38 penderita drop-out, 8 penderita pindah ke pelayanan kesehatan lain, dan 28 penderita meninggal.

Pada penelitian ini dengan follow-up selama 6 bulan terdapat 2 kasus kematian pada kelompok tidak anemia dan 26 kematian pada kelompok anemia.

Kasus kematian yang terdapat pada penelitian ini terutama terjadi pada penderita HIV-AIDS laki-laki berusia 20-29 tahun, dengan IMT $<18,5$. Pada penderita dengan IMT 25-29,9 tidak terjadi kematian dalam pengamatan selama enam bulan (Tabel 1). Kematian berdasarkan derajat anemia didapatkan hasil sebagai berikut: pada penderita dengan anemia ringan menunjukkan $\mathrm{RR}=17,43$ (95\% IK: 4,13-73,48), pada anemia sedang dan berat dengan $\mathrm{RR}=22,94$ (95\% IK: 4,63-113,76). Untuk anemia secara keseluruhan $\mathrm{RR}=18,27$ (95\% IK: 4,38-76,19).

Kematian terutama terjadi pada kelompok penderita HIV-AIDS dengan jumlah CD4 1-50 $\mathrm{sel} / \mathrm{mm}^{3}$. Hasil pengamatan terhadap VL pada kelompok yang meninggal tampak bahwa sebanyak $53,8 \%$ menunjukkan VL yang masih tinggi (Tabel

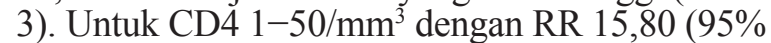

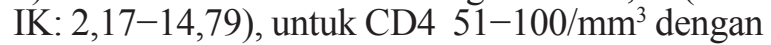
RR 5,96 (95\% IK: 0,69-51,88).

Untuk kematian berdasarkan VL: VL $>10.000$ kopi/mm³ dengan RR 7,67 (95\% IK: 2,04-28,87). Untuk VL 150-100.000 kopi/mm $\mathrm{mm}^{3}$ dengan RR 10,45 (95\% IK: 2,24-48,74). Selanjutnya dilakukan uji regresi logistik ganda untuk semua karakteristik (Tabel 4).

Nilai CD4 dan derajat anemia mempunyai nilai hazard ratio (HR) paling tinggi untuk terjadinya kematian, sedangkan IMT mempunyai nilai protektif.

Peluang terjadinya kematian pada penderita HIV/AIDS dari berbagai faktor risiko dihitung mempergunakan analisis regresi logistik ganda, hasilnya diperoleh model:

$\mathrm{p}($ mati $)=\frac{1}{1+\exp -\left(-4,781-1,681^{*} \mathrm{IMT}+0,999^{*} \text { Derajat Anemia }+1,391{ }^{*} \mathrm{CD} 4\right)}$

Peluang kematian paling besar terdapat pada kelompok penderita anemia sedang-berat dengan CD4 $\leq 50 \mathrm{sel} / \mathrm{mm}^{3}$ dan IMT $<18,5$; kemudian disusul oleh anemia ringan dengan IMT $<18,5$ dan CD4 $\leq 50 \mathrm{sel} / \mathrm{mm}^{3}$ (Tabel 5). 
Rachmat: Peluang Kematian Penderita Human Immunodeficiency Virus-Acquired Immune Deficiency Syndrome

Tabel 1 Hubungan Berbagai Karakteristik Demografi dengan Outcome

\begin{tabular}{|c|c|c|c|}
\hline \multirow{2}{*}{ Karakteristik } & \multicolumn{2}{|c|}{ Outcome $(\mathrm{n} * *)$} & \multirow{2}{*}{$\mathbf{p}^{*}$} \\
\hline & Mati & Hidup (\%) & \\
\hline Jenis kelamin & & & 0,066 \\
\hline Laki-laki & $25 / 28$ & $373 / 506(73,7)$ & \\
\hline Perempuan & $3 / 28$ & $133 / 506(26,3)$ & \\
\hline Usia (tahun) & & & 0,896 \\
\hline $14-19$ & 0 & $6 / 506(1,2)$ & \\
\hline $20-29$ & $19 / 28$ & $298 / 506(58,9)$ & \\
\hline $30-39$ & $8 / 28$ & $184 / 506(36,4)$ & \\
\hline $40-49$ & $1 / 28$ & $15 / 506(2,9)$ & \\
\hline$\geq 50$ & 0 & $3 / 506(0,6)$ & \\
\hline SD & $30,0(6,2)$ & $29,2(4,9)$ & \\
\hline Rentang & $21-48$ & $16-56$ & $<0,001$ \\
\hline \multicolumn{4}{|l|}{ IMT } \\
\hline$<18,5$ & $18 / 22$ & $13 / 345(3,8)$ & \\
\hline $18,5-22,9$ & $3 / 22$ & $229 / 345(66,4)$ & \\
\hline $23-24,9$ & 0 & $49 / 345(14,2)$ & \\
\hline $25-29,9$ & 0 & $49 / 345(14,2)$ & \\
\hline$\geq 30$ & $1 / 22$ & $5 / 345(1,4)$ & \\
\hline
\end{tabular}

* Nilai p dihitung berdasarkan uji chi-kuadrat

** Jumlah kasus (n) tercantum setelah tanda garis miring untuk setiap data

\section{Pembahasan}

Penelitian di tempat yang sama, yaitu di klinik Teratai RSHS, dilaporkan prevalensi anemia sebesar $41,6 \%$. Faktor risiko yang berperan untuk anemia pada penderita infeksi HIV pada penelitian tersebut yaitu kandidiasis oral, IMT rendah, dan CD4, sedangkan antiretroviral bersifat protektif. ${ }^{6}$ Sullivan dan Buskin ${ }^{8}$ melaporkan prevalensi anemia sebesar $77 \%$ pada periode pengamatan 2.408 penderita infeksi HIV tahun 1996-2001. Pada penderita infeksi HIV dengan CD4 $<100 \mathrm{sel} /$ $\mathrm{mm}^{3}$, tidak menunjukkan penurunan prevalensi anemia. Hal ini berarti bahwa meskipun telah ada perkembangan dalam pengobatan infeksi HIV berupa highly active anti retroviral therapy (HAART) yang dimulai pada tahun 1996, akan tetapi prevalensi anemia tetap tinggi. ${ }^{5,8}$

Penelitian metaanalisis oleh Belperio dan Rhew $^{4}$ menunjukkan bahwa penderita infeksi HIV dengan anemia mempunyai risiko kematian tinggi dibandingkan dengan yang tidak anemia, meskipun sudah dikoreksi dengan jumlah CD4 dan VL yang juga mempengaruhi kematian. Kesimpulan berdasarkan beberapa penelitian yang ditelaah oleh Belperio dan Rhew $^{4}$ bahwa kenaikan hemoglobin $1 \mathrm{~g} / \mathrm{dL}$ akan menurunkan kematian sebesar $28 \%$, kemudian $83 \%$ penderita dengan hemoglobin $\geq 12 \mathrm{~g} / \mathrm{dL}$ dapat bertahan hidup 44 minggu, sedangkan pada kelompok hemoglobin $<10 \mathrm{~g} / \mathrm{dL}$ hanya $56 \%$. Setelah 30 bulan kematian pada penderita dengan hematokrit $<35 \%$ menjadi 1,57 kali lebih tinggi dibandingkan dengan hematokrit $\geq 35 \%$.

Petunjuk untuk mengetahui risiko kematian pada penderita HIV-AIDS perlu diketahui sejak awal penderita datang ke fasilitas kesehatan, agar dapat dilakukan usaha yang maksimal untuk mengatasi penderita HIV-AIDS. Usaha yang dimaksud antara lain pemberian ARV lebih awal sesuai dengan kriteria WHO, pemberian medikamentosa untuk infeksi oportunistik, dan perbaikan gizi penderita.

Srasuebkul dkk. ${ }^{16}$ telah mengajukan cara yang lebih sederhana untuk menilai progresivitas infeksi HIV berdasarkan hasil penelitian 4.573 penderita HIV-AIDS. Variabel yang dipergunakan yaitu usia, jenis kelamin, derajat anemia, IMT, CD4, dan VL. Penderita dibagi dalam kelompok risiko rendah, sedang, dan tinggi untuk terjadi progresivitas atau kematian. Risiko rendah bila usia $\geq 40$ tahun, wanita, IMT $>18$, tidak anemia, VL tidak terdeteksi, dan CD4 $>200 \mathrm{sel} / \mathrm{mm}^{3}$. Risiko sedang bila wanita, usia $<40$ tahun, anemia 
Tabel 2 Hubungan Berbagai Faktor Karakteristik Klinis dengan Outcome

\begin{tabular}{|c|c|c|c|}
\hline \multirow{2}{*}{ Karakteristik } & \multicolumn{2}{|c|}{ Outcome $(\mathrm{n} * *)$} & \multirow{2}{*}{$\mathbf{p}^{*}$} \\
\hline & Mati & Hidup (\%) & \\
\hline TB $(+)$ & $3 / 28$ & $46 / 492(9,3)$ & 0,810 \\
\hline IDU $(+)$ & $22 / 28$ & $361 / 482(74,9)$ & 0,662 \\
\hline Kandidiasis oral (+) & $5 / 18$ & $73 / 412(17,7)$ & 0,278 \\
\hline \multicolumn{4}{|l|}{ Stadium } \\
\hline I & $5 / 21$ & $57 / 352(16,2)$ & 0,437 \\
\hline II & 0 & $29 / 352(8,2)$ & \\
\hline III & $9 / 21$ & $131 / 352(37,2)$ & \\
\hline IV & $7 / 21$ & $135 / 352(38,4)$ & \\
\hline \multicolumn{4}{|l|}{ Derajat anemia } \\
\hline Tidak anemia & $2 / 28$ & $310 / 506(61,3)$ & $<0,001$ \\
\hline Ringan & $21 / 28$ & $167 / 506(33,0)$ & \\
\hline Sedang-berat & $5 / 28$ & $29 / 506(5,7)$ & \\
\hline \multicolumn{4}{|l|}{ Anemia } \\
\hline+ & $26 / 28$ & $196 / 506(38,7)$ & $<0,001$ \\
\hline- & $2 / 28$ & $310 / 506(61,3)$ & \\
\hline $\mathrm{Hb}(\mathrm{g} / \mathrm{dL})$ & & & 0,001 \\
\hline SD & $10,69(1,64)$ & $11,79(1,78)$ & \\
\hline Rentang & $7,5-13,8$ & $5-16,9$ & \\
\hline
\end{tabular}

* Nilai p dihitung berdasarkan uji chi-kuadrat

** Jumlah kasus (n) tercantum setelah tanda garis miring untuk setiap data

sedang, CD4 51-200 sel $/ \mathrm{mm}^{3}$, tanpa pemeriksaan VL. Risiko tinggi bila anemia berat, BMI $\leq 18$, CD4 $\leq 50 \mathrm{sel} / \mathrm{mm}^{3}$, dan VL terdeteksi. Srasuebkul dkk. ${ }^{16}$ menyimpulkan bahwa IMT yang rendah $(\leq 18)$, dan anemia berat $(\mathrm{Hb} \leq 8 \mathrm{~g} / \mathrm{dL})$ merupakan faktor prediktif pada ketiga kelompok tersebut di atas. Pada penelitian penulis, faktor risiko yang berperan terhadap kematian yaitu IMT, derajat anemia, dan CD4 (Tabel 5). Cluster differentiation 4 menunjukkan HR (hazard ratio) yang paling tinggi, disusul oleh derajat anemia, sedangkan IMT bersifat protektif. Gabungan anemia sedang-berat dan IMT $<18,5$, serta CD4 $\leq 50 / \mathrm{mm}^{3}$ merupakan kombinasi yang menunjukkan peluang kematian terbesar $(0,801)$ (Tabel 6). Pada penderita dengan anemia sedang-berat tetapi CD4 $>100 / \mathrm{mm}^{3}$ dan IMT $<18,5$ memperlihatkan kemungkinan kematian tidak tinggi $(0,199)$.

Telah diteliti bahwa faktor risiko kegagalan ARV antara lain adherence yang buruk, VL tinggi, CD4 rendah, kunjungan kurang teratur, dan usia muda. Dari faktor risiko tersebut, adherence merupakan faktor risiko paling penting. Untuk keberhasilan pengobatan ARV adherence harus baik, artinya penderita hanya boleh lupa minum obat tidak $>2$ kali dalam satu bulan. Adherence yang buruk akan mempercepat resistensi obat dan meningkatkan kembali VL. Perlu diingat bahwa adherence ini sangat dipengaruhi oleh efek samping obat atau faktor psikososial. ${ }^{14}$ Pada penelitian ini tampak bahwa adherence tidak mempunyai nilai bermakna $(p=0,712)$ untuk kematian, agaknya sebagai akibat kurangnya tercantum masalah adherence pada data basis, hanya terdapat sebanyak 294 catatan tentang adherence.

Dari data dasar yang ada tidak tercantum sebab kematian dengan rinci, sehingga sulit untuk mengevaluasi penyebab kematian yang tepat pada penderita infeksi HIV pada penelitian ini. Penulis berpendapat bahwa diagnosis pneumosistis perlu ditegakkan dengan benar mengingat pneumosistis merupakan penyebab kematian yang penting. Pada CD4 $<100 / \mathrm{mm}^{3}$, pneumonia pneumosistis terjadi pada 50\% kasus AIDS dan akan bertambah tinggi mencapai $75 \%$ bila CD4 $<50 / \mathrm{mm}^{3}$. Pada penelitian ini penulis mendapatkan kematian terutama pada penderita dengan CD4 $1-50 \mathrm{sel} /$ $\mathrm{mm}^{3}(22 / 27$ penderita), suatu jumlah yang sesuai dengan infeksi pneumosistis.

Menurut kepustakaan jika obat ARV berefek 
Tabel 3 Hubungan Berbagai Faktor Karakteristik Pengobatan dan Hasil Laboratorium dengan Outcome

\begin{tabular}{|c|c|c|c|}
\hline \multirow{2}{*}{ Karakteristik } & \multicolumn{2}{|c|}{ Outcome } & \multirow{2}{*}{$\mathbf{p}$} \\
\hline & Mati & Hidup (\%) & \\
\hline ARV (ya) & $8 / 27$ & $259 / 497(52,1)$ & 0,023 \\
\hline Adherence (buruk) & $0 / 17$ & $17 / 288(5,9)$ & 0,712 \\
\hline \multicolumn{4}{|l|}{ CD4 } \\
\hline$>200$ & 0 & $283 / 498(56,8)$ & $<0,001$ \\
\hline $10-200$ & $1 / 27$ & $78 / 498(15,6)$ & \\
\hline $51-100$ & $4 / 27$ & 49/498 $(9,8)$ & \\
\hline $1-50$ & $22 / 27$ & $88 / 498(17,7)$ & \\
\hline \multicolumn{4}{|l|}{ VL } \\
\hline$<150$ & $3 / 13$ & $227 / 309(73,5)$ & $<0,001$ \\
\hline $150-10.000$ & $3 / 13$ & $19 / 309(6,1)$ & \\
\hline$>10.000$ & $7 / 13$ & $63 / 309(20,4)$ & \\
\hline
\end{tabular}

ARV: antiretroviral, VL: viral load

Tabel 4 Hubungan Berbagai Faktor yang Mempengaruhi Kematian berdasarkan Uji Regresi Logistik

\begin{tabular}{lcc}
\hline \multicolumn{1}{c}{ Variabel } & p & HR (95\% IK) \\
\hline IMT & 0,008 & $0,187(0,054-0,644)$ \\
Derajat anemia & 0,020 & $2,715(1,167-6,313)$ \\
CD4 & 0,021 & $4,018(1,231-13,112)$ \\
\hline K
\end{tabular}

Keterangan: HR $=$ hazard ratio

baik, maka setelah enam bulan jumlah virus akan berkurang banyak, sehingga VL tidak terdeteksi. Bila pada pengamatan setelah enam bulan VL meningkat atau tidak menunjukkan penurunan yang jelas disebut sebagai virologic failure. Hal ini merupakan petunjuk beberapa hal, apakah adherence yang kurang baik atau virus sudah resisten. Hal ini merupakan indikasi untuk mengubah atau mengganti protokol ARV., ${ }^{5,7}$ Pada penelitian ini jumlah CD4 baik pada kelompok anemia maupun tidak, setelah 6 bulan pengamatan kadarnya meningkat dan secara statistik sangat bermakna. Viral load baik pada kelompok anemia maupun tidak anemia, tidak terdapat penurunan yang bermakna, hal ini terjadi karena jumlah pemeriksaan VL yang kurang seimbang sehingga secara statistik tidak bermakna.

Belperio dan $\mathrm{Rhew}^{4}$ membandingkan risiko kematian antara penderita infeksi HIV yang anemia dan tidak anemia. Masa hidup rata-rata

Tabel 5 Peluang Kematian dari Berbagai Kombinasi Faktor Risiko Kematian

\begin{tabular}{ccccc}
\hline CD4 & IMT & Derajat Anemia & p (Mati) & p (Hidup) \\
\hline$\leq \mathbf{5 0}$ & $<\mathbf{1 8 , 5}$ & Sedang-berat & $\mathbf{0 , 8 0 1}$ & $\mathbf{0 , 1 9 9}$ \\
$\leq 50$ & $<18,5$ & Ringan & 0,597 & 0,403 \\
$51-100$ & $<18,5$ & Sedang-berat & 0,500 & 0,500 \\
$\leq 50$ & $18,5-22,9$ & Sedang-berat & 0,428 & 0,572 \\
$51-100$ & $<18,5$ & Ringan & 0,269 & 0,731 \\
$\leq 50$ & $18,5-22,9$ & Ringan & 0,216 & 0,784 \\
$>100$ & $<18,5$ & Sedang-berat & 0,199 & 0,801 \\
\hline
\end{tabular}

p: peluang 
(median survival) kelompok anemia secara nyata lebih pendek dibandingkan dengan kelompok tidak anemia, tidak bergantung pada jumlah CD4. Rasio risiko kematian sebesar $1,4(95 \%$ IK: $1,1-1,8)$ pada kelompok penderita dengan CD4 antara 100-149/ mm sampai 2,5 (95\% IK: 2,1-2,9) pada kelompok penderita dengan CD4 $\geq 200 / \mathrm{mm}^{3}$. Terlihat pula bahwa pada penderita yang menjadi tidak anemia lagi masa hidupnya lebih panjang, yaitu 23-64 bulan pada kelompok yang menjadi tidak anemia lagi dan 12-36 bulan pada kelompok yang tetap anemia. Pada kelompok penderita dengan CD4 $<200 \mathrm{sel} / \mathrm{mm}^{3}$ risiko kematian bertambah $56 \%$ bila terdapat anemia. Risiko kematian menjadi 0,37 (95\% IK: 0,33-0,43) pada kelompok yang tidak anemia lagi. Belperio dan $\mathrm{Rhew}^{4}$ mendapatkan bahwa penurunan kadar $\mathrm{Hb} 1 \mathrm{~g} / \mathrm{dL}$ meningkatkan risiko kematian 57\%, dengan HR 1,57 (95\% IK: 1,41-1,75). Penurunan 50\% dari jumlah CD4 akan meningkatkan risiko kematian 51\%, dengan HR 1,51 (95\% IK: 1,35-1,70), sedangkan peningkatan satu log dari VL akan meningkatkan kematian 37\%, dengan HR 1,37 (95\% IK: 1,15-1,63). Pada penelitian tersebut disimpulkan bahwa kadar $\mathrm{Hb}$ merupakan marka prognostik kuat untuk kematian. Dalam penelitian ini VL tidak muncul sebagai faktor risiko dalam peluang kematian, hal ini sudah diduga sejak awal penelitian karena jumlah pemeriksaan yang kurang.

Simpulan, gabungan derajat anemia, IMT, dan jumlah CD4 merupakan petunjuk terjadinya kematian pada penderita HIV-AIDS. Faktor risiko yang penting untuk kematian penderita HIV-AIDS yaitu CD4, derajat anemia, dan IMT. Gabungan derajat anemia sedang-berat, CD4 $\leq 50 / \mathrm{mm}^{3}$, dan IMT $<18,5$ menunjukkan peluang kematian yang terbesar bagi penderita HIV-AIDS.

\section{Daftar Pustaka}

1. UNAIDS. AIDS epidemic update: global summary of the AIDS epidemic. Geneva: WHO Library Cataloguing Data; 2007.

2. UNAIDS. The global HIV challenge. Report on the global AIDS epidemic. Geneva: WHO Library Cataloguing Data; 2008.

3. WHO. Review of the health sector response to HIV and AIDS in Indonesia 2007. NewDelhi: WHO Library Cataloguing data. World Health Organization, Regional Office for South-East Asia; 2007.

4. Belperio PS, Rhew DC. Prevalence and outcomes of anemia in individuals with human immunodeficiency virus: a systematic review of the literature. Am J Med. 2004;16(7A):27-43.

5. Volberding PA, Levine AM, Dieterich D, Mildvan D, Mitsuyasu R, Saag M. Anemia in
HIV infection: clinical impact and evidencebased management strategies. Clin Infect Dis. 2004;38:1454-63.

6. Sumantri R, Wicaksana R, Ariantana AR. Prevalensi dan faktor risiko anemia pada HIV-AIDS. MKB. 2009;41(4):187-93.

7. Semba RD, Shah N, Klein RS, Mayer KH, Schuman P, Vlahov D, dkk. Prevalence and cumulative incidence of and risk factors for anemia in a multicenter cohort study of human immunodeficiency virus-infected and-uninfected women. Clin Infect Dis. 2002;34:260-6.

8. Sullivan P, Buskin S. Early diagnosis and appropriate treatment of HIV-related anemia important to survival of the HIV-positive. The $2^{\text {nd }}$ International AIDS Society Conference on HIV Pathogenesis and Treatment. July $14^{\text {th }}$, Poster 1154, 2003.

9. Brokering KL, Qaqish RB. Management of anemia of chronic disease in patients with the human immunodeficiency virus. Pharmacotherapy. 2003;23(11):1475-85.

10. PERKENI. Konsensus pengelolaan dan pencegahan diabetes melitus tipe-2 di Indonesia 2006. Jakarta: Pengurus Besar Perkumpulan Endokrinologi Indonesia; 2006.

11. WHO. Management of HIV infection and antiretroviral therapy in adults and adolescent: a clinical manual. Geneva: WHO Technical Publication; 2007.

12. Lidya R, Rutherford M, Apriani L, Janssen W, Rahmadi A, Parwati I, dkk. Improving diagnosis of pulmonary tuberculosis among HIV/AIDS patients: literature review and experience in a teaching hospital in Indonesia. Acta Med Indones. 2009;41(Suppl 1):57-64.

13. Pulungsih SP. Pedoman nasional terapi antiretroviral. Jakarta: Depkes RI; 2004.

14. Bangsberg DR, Acosta EP, Gupta R, Guzman D, Riley ED, Harrigan DR, dkk. Adherenceresistance relationships for protease and nonnucleoside reverse transcriptase inhibitors explained by virological fitness. AIDS. 2006; 20:223.

15. Glassman AB. Anemia, diagnosis and clinical considerations. Dalam: Harmening DM, penyunting. Clinical hematology and fundamentals of hemostasis. Edisi ke-4. Philadelphia: F.A.Davis Company; 2002. hlm. 74-83.

16. Srasuebkul P, Poh LL, Man PL, Kumarasany N, Zhou J, Sirisanthana S, dkk. Shortterm clinical disease progression in HIVinfected patients receiving combination antiretroviral therapy: result from the TREAT Asia HIV Observational Database. CID. 2009;48:940-50. 